\title{
Influence of Marketing Strategy, Brand Image and Customer Satisfaction Product Purchasing Decisions "We" at Bulog Subdivre Makassar
}

\section{Sitti Mardati ${ }^{1}$, Milka P ${ }^{2}$, Jumidah Maming ${ }^{3}$, Harry K. ${ }^{4}$, Andi Reni ${ }^{5}$ and Ahmad Daeng GS ${ }^{6}$}

\author{
${ }^{1}$ Hasanuddin University, Indonesia \\ ${ }^{2}$ Hasanuddin University, Indonesia \\ ${ }^{3}$ Hasanuddin University, Indonesia \\ ${ }^{4}$ Hasanuddin University, Indonesia \\ ${ }^{5}$ Hasanuddin University, Indonesia \\ ${ }^{6}$ Hasanuddin University, Indonesia
}

\begin{abstract}
The purpose of this study is to determine whether the dimensions of innovation culture, motivation, and entrepreneurship orientation affect the advantage competition of SMEs in South Sulawesi Province in selected districts/cities owned by Women Entrepreneurs. The population in this study is SMEs in South Sulawesi Province in selected districts/cities that are owned by Women Entrepreneurs. Samples taken were 83 respondents using the Non-Probability Sampling technique with a Purposive approach sampling, which is sampling based on specific targets, while the sampling criteria are female entrepreneur respondents in SMEs in South Sulawesi Province. Based on the results of the study, the regression equation is obtained as follows: $\mathrm{Y}=1.005+0.221 \mathrm{X} 1+0.229 \mathrm{X} 2$ $+0.585 \mathrm{X} 3$. Based on statistical data analysis, all indicators in this study are valid, and all variables are reliable. In classical assumption testing, multicollinearity-free regression models, heteroscedasticity does not occur, and data normally distributed. The most influential variable is the entrepreneurship orientation variable with a regression coefficient of 0.585 , then motivation variable with a regression coefficient of 0.229 , then innovation culture variable with a regression coefficient of 0.221. SMEs in South Sulawesi Province in selected districts/cities owned by Women Entrepreneurs need to maintain elements that have been considered good so that SMEs in South Sulawesi Province can compete and need to improve things that are considered lacking.
\end{abstract}

Keywords: Entrepreneurship, women entrepreneurs

\section{Introduction}

Today every company, both engaged in the product or service, the goal is to survive and thrive, these objectives can be achieved through efforts to maintain and improve the level of profit or operating profit of the company. This can be done, if the company can maintain and increase sales of products they produce. By performing accurate implementation of marketing strategies through the use of the opportunities to increase sales, so that the position or the position of the company in the market can be improved or maintained.

The marketing strategy is an effort to find a favorable marketing position in an industry or a fundamental arena of competition takes place. Marketing in companies, in addition to the dynamic action of the old habits that no longer exists and continue to innovate in the marketing strategy. Companies engaged in the food sector is an industry that must constantly improve the quality of their products and the good quality of the marketing strategy.

Food products such as rice has a very important role in the life of Indonesian society is seen from the economic aspect. Mangilep (2015) states that a rice stocks is an important aspect of Indonesians. In order to carry out its duties and functions, legal status of the Public Company Bulog is a NonDepartmental Government Institutions (Officials) based KEPPRESRI 39 1978. Based on Government Regulation No. 72003 Bulog the Public Company. As a SOE (State Owned Enterprises) in the form of Housing (Public Company), Bulog institutions continue to carry two (2) mandated tasks to be carried, the public service tasks and duties of a commercial nature. In the realm of public 
service Perum Bulog has been formally designated as the sole government agency responsible for managing food staples of rice. In a further development, as is known Perum Bulog has a strategic role in national food security, Perum Bulog as a state which has the task of PSO (Public Service Obligation) is to maintain price stability in the level of producer and consumer. The role and function of Perum Bulog is absolutely manage a single commodity, such as rice. But in carrying out the duties of a commercial nature have broader authority to manage multi-commodity businesses including food commodities, such as sugar, corn, soybeans, and so on.

Nowadays if we review the development of the rice business Perum Bulog, both of which lead to the development of the rice industry and that are trading, impressed fluctuated and is not optimal in its development than the potential of Perum Bulog, as industrial SOEs Perum Bulog implement a marketing strategy that is always innovating, Perum Bulog's sales strategy is to sell to the public market in retail and wholesale, in cooperation with the Cooperative as well as through the distribution center (DC) and outlet Bulog Mart (www.bulog.co.id).

Food House BULOG We are partners and a network of sales outlets staple food. Community-owned sales outlets and nurtured by Perum Bulog is aimed at keeping the price stability in the midst of society. Perum Bulog through this House concept Food We define strategies and programs that increase the production and sale of essential food commodities for commercial use. There are some commodities that are sold as rice ( $\mathrm{C} 4$, medium, menthik fragrant, sun, red, menthik milk), sugar, cooking oil, flour and eggs. (Www.bulog.co.id).

Perum Bulog conducting business with several activities, including the management of commodity rice, sugar, soy, meat, fish and other commodities. Increased sales of South Sulawesi Bulog level can be described through the data absorption of rice farmers throughout 2017. By the end of August 2017, the realization of the national rice penetrate absorption of 1.7 million tons. Absorption of rice in the province amounted to 58.7 percent is the highest nationwide. Uptake Sulsel better than Java (56.27 percent), Sulawesi (53.99 percent) and West Java (52.53 percent).

Being asked about the stock of rice in Bulog Sulselbar, Dindin calls so far penetrated 147 thousand tons. Hundreds of thousands of tons of rice was distributed in 11 sub-Divre in two provinces. SubDivision of Parepare highest rice store reaches 37 thousand tons of food security of up to 170 months. Followed by Sub-Division Sidrap with 23 thousand tons of rice stocks (food security 68 months). As for that low of Sub-Division Mamuju with 1.5 tons of rice stocks (food security 6 months). Overall, the food security of rice in the province to secure up to 2 years. With a stock of 147 thousand tons, not to be consumed. Hence, we send rice from South Sulawesi province to another. Starting from Papua, Ambon, Jakarta and Batam. (Http://wartaekonomi.co.id).

Implementation of Product marketing Houses We have a very large role as a support directly to the company's sales Bulog, so that by the application of the concept of a marketing strategy that accurately through the use of the opportunities in sales, the position or the position of the company in the market can be improved or maintained so that it can have a significant impact with satisfaction customer. Customer satisfaction felt by the community become a strategic role to build a good brand image among companies in food sector.

Perum Bulog Subdivision Makassar as acting public of Bulog in this case Raskin for some regions such as Makassar, Gowa, Takalar, Maros and Pangkep require significant costs for activities Raskin distribution which resulted in duty commercial of Perum Bulog not earn a profit / a good profit. Particularly in 2016 Perum Bulog Makassar Subdivision using distribution costs amounted Rp.517.338.900,00 (Perum Bulog source Makassar Subdivision) in the distribution of Raskin in Makassar. This resulted in net income / profit obtained is not optimal. To optimize the distribution costs needed some systematic planning so that the cost for distribution Raskin be optimal.

Based on the existing reality, is what lies behind this research is to provide solutions in order to optimize the implementation of marketing strategies that look at the level of brand image and customer satisfaction Bulog, especially in the city of Makassar. In connection with that, this research 
will focus on how your influence marketing strategy, brand image, customer satisfaction on product purchasing decisions "KITA" at Bulog Subdivre Makassar.

\section{Research Methodology}

This study uses a quantitative approach, by collecting primary data obtained through the method of distributing questionnaires in the city of Makassar. According Sugiyono (2013), the quantitative research method can be interpreted as a method of research that is based on the philosophy of positivism, is used to study in the population or a particular sample, sampling technique generally random, collection and use of research instruments, analysis of quantitative data by using tools analysis Structural Equation Modeling (SEM), with the aim to test the hypothesis has been established that the relationship between the independent variables and the dependent variable indicator of the relationship between each independent variable. SEM is a statistical modeling technique that is crosssectional, linear and general (Jonathan, 2008).

Research will be conducted in the city of Makassar, which will be held in November-December 2018. The time spent during the study estimated that approximately two months.

Sampling using purposive sampling method, which takes a sample of the population based on criteria set by the researchers. By using slovin formula is as follows:

Where :

$$
n=\frac{N}{1+\left(N \times e^{2}\right)}
$$

$\begin{array}{ll}\mathrm{n} & =\text { Number of samples } \\ \mathrm{N} & =\text { Total population } \\ \mathrm{e} & =\text { The critical value }(5 \%) \\ 1 & =\text { Figures constant }\end{array}$

From this formula, the number of sampling can be calculated as follows:

$$
n=\frac{N}{1+\left(N \times e^{2}\right)}
$$

In this study, the type of data is quantitative data, where the data is a number that is ready to be processed derived from the questionnaire.

The primary data used in this study was obtained from the results of questionnaires on a predetermined number of samples were respondents in this study. Primary data in the form of raw data by the determination of Likert scale.

Secondary data used were obtained in the form of data or the agency's corporate documents and other written information with links that are relevant to this study.

In obtaining the data, information or supporting various theories as in this study, researchers used data collection techniques done by spreading the questionnaire directly to the respondent. This questionnaire consists of questions that load each indicator questions of each study variable and the identity of these respondents clearly and collection of materials and information from this study comes from the literature / journals, books, written reports and other references that underlie theory in this study.

In this study there are three variables, namely:

1. Independent Variables (X)

Variable independent or often referred to as the independent variable, which is divided into two: marketing strategy (X1) and brand image (X2)

2. Dependent Variable (Y)

The dependent variable is often referred to as the dependent variable is the variable $\mathrm{Y}$ research is customer satisfaction (Y1) and purchasing decisions (Y2). 
The instrument used was a questionnaire that has been tested for validity, in these measurements, researchers used a Likert scale associated with a statement about the attitude / perception of someone about something, for example, agree-disagree, happy-not happy, and good-not good. The way the measurement is to confront a respondent with several statements posed in the questionnaire and then were asked to provide answers. Data collected from the questionnaires will then be measured by calculating the weight of 1 to 5 , with the categories:

a. Strongly agree with: Weight 5

b. Agree with : Weight 4

c. Not agree with : Weight 3

d. Disagree with : Weight of 2

e. Strongly Disagree : Weight 1

In the data processing responders, researchers will use SEM) with Amos 23. Structural Equation Modeling (SEM) is a statistical technique that is capable of analyzing the independent variable, the variable observed, and measurement error directly. SEM is able to analyze the relationship between independent variables with the indicator, the relationship between independent variables with each other independent variables, as well as to determine the measurement error (Vitello, 2008). In SEM needed information that describe relationships between variables, so it is necessary to analyze path (path).

Path (Path) is information indicating the link between the construct with another construct.

SEM has properties as a multivariate analysis technique which includes special versions in the number of other analytical methods as special cases, so that SEM has the characteristics of analytical techniques to further assert than to explain (Jonathan, 2008). SEM is used to build and test models of aspects of confirmation (confirmatory) of the factor analysis, path analysis and regression. In this study, the stages that must be passed in data processing, namely normality test, Confirmatory Factor Analysis (CFA).

\section{Results and Discussion}

The characteristics of the samples in this study are described on gender, age, education, end, job, future use of the product "KITA" at Bulog Subdivre. Interest exposure characteristics of the entire sample was to determine the effectiveness of the results obtained. The study subjects were Consumer Products "KITA" at Bulog Subdivre.

Characteristics of Respondents by Gender. Based on the results of research conducted to 100 respondents who are Consumer Products "KITA" at Perum Bulog in Makassar Subdivre acquired the characteristics of respondents by sex.

Characteristics of respondents by sex can be seen in table as follows:

Table Characteristics of respondents by sex

\begin{tabular}{|l|l|l|}
\hline Gender & $\begin{array}{l}\text { Frequency } \\
\text { (person) }\end{array}$ & $\begin{array}{l}\text { Percentage } \\
(\%)\end{array}$ \\
\hline Man & 80 & $80 \%$ \\
\hline woman & 20 & $20 \%$ \\
\hline total & 100 & $100 \%$ \\
\hline
\end{tabular}

Based on the table above, it can be seen that the participants of same-sex male have highest number of 80 people or $80 \%$ compared with women of 20 people or $20 \%$. This suggests that male respondents consume more products "KITA". 
Table 1. Characteristics of respondents by age

\begin{tabular}{|l|l|l|}
\hline $\begin{array}{l}\text { Age } \\
\text { (Years) }\end{array}$ & $\begin{array}{l}\text { Frequency } \\
\text { (person) }\end{array}$ & $\begin{array}{l}\text { Percentage } \\
(\%)\end{array}$ \\
\hline $30-39$ & 12 & $12 \%$ \\
\hline $40-49$ & 55 & $55 \%$ \\
\hline$>50$ & 33 & $33 \%$ \\
\hline total & 100 & \multicolumn{1}{|c|}{$100 \%$} \\
\hline
\end{tabular}

Based on the data in the table above that, on average, in this study the majority of respondents have levels between 40-49 years of age, this indicates that respondents who consume the product "KITA" in this study is largely the respondents who have a productive age, so in general it can be said that the majority of consumers who consume the product "KITA" is the productive age and work.

The above table shows that, based on the characteristics of respondents by education, it is known that most of the respondents have the highest S2 education at 64 or $64 \%$ and the lowest S3 Education for 8 people or $8 \%$. This shows that the majority of consumers of products "KITA" have completed a bachelor's degree.

Table 2. Characteristics of Respondents by Job

\begin{tabular}{|l|l|l|}
\hline Work & $\begin{array}{l}\text { Frequency } \\
\text { (person) }\end{array}$ & $\begin{array}{l}\text { Percentage } \\
(\%)\end{array}$ \\
\hline PNS & 12 & $12 \%$ \\
\hline $\begin{array}{l}\text { Private } \\
\text { employees }\end{array}$ & 18 & $18 \%$ \\
\hline $\begin{array}{l}\text { entrepreneu } \\
\text { r }\end{array}$ & 70 & $70 \%$ \\
total & 100 & $100 \%$ \\
\hline
\end{tabular}

The above table illustrates that the consumer products "KITA" which netted as respondents in this study, showed that of the Self (70), followed by each of the Private Employees (18 persons), civil servants (12).

Object of research is the influence of marketing strategy, brand image, customer satisfaction on product purchasing decisions "KITA" at Bulog Subdivre Makassar. The independent variable of this research is a marketing strategy that consists of product, price and promotion. The dependent variable of this research is consumer satisfaction and consumer loyalty.

Variable Products (X1). Variable product consists of four items statement to see how variable products through forms of packaging, quality, halal labels, aesthetics.

Selection of respondents is composed of strongly disagree, disagree, undecided, agree and strongly agree that transformed into a Likert scale of 1 to 5 with the figure 1 shows the perception strongly disagree and 5 indicates strongly agree to statement filed.

Descriptive statistical results of respondents' answers on variable products in table show that the majority of respondents answered strongly agreed with the statement proposed. In the appendix, the answer choices strongly agree as much as 55 and 45 . Respondents who chose not to hesitate as much as 7 and the 5 remaining disagree strongly disagree provide an answer as much as 1 . This shows that respondents in this case the customer could not agree on variable products.

Variable Price (X2). Variable Price consists of 4 items looking statements concerning product prices "KITA" of the offer. 
Selection of respondents is composed of strongly disagree, disagree, undecided, agree and strongly agree that transformed in the form of a Likert scale of 1 to 5 with the figure 1 shows the perception strongly disagree and 5 indicates strongly agree to statement filed.

Table 3. Descriptive Statistics of Product

\begin{tabular}{|l|l|l|}
\hline Scale & Frequency & Percentage (\%) \\
\hline $1=$ Strongly Disagree & 1 & 1 \\
$2=$ Disagree & 5 & 5 \\
$3=$ Undecided & 7 & 7 \\
$4=$ Agree & 45 & 45 \\
$5=$ Strongly Agree & 55 & 55 \\
\hline Total & 100 & 100 \\
\hline
\end{tabular}

Results of respondents' descriptive statistics on variables in table shows the price of an average of 44 answers strongly agree and agree as much as 36 answers and the answers strongly disagree 4 disagree 7 and hesitation are 9 answers.

Table 4. Descriptive Statistics of Variable Price

\begin{tabular}{|l|l|l|}
\hline Scale & Frequency & $\begin{array}{l}\text { Percentage } \\
(\%)\end{array}$ \\
\hline $1=$ Strongly Disagree & 4 & 4 \\
$2=$ Disagree & 7 & 7 \\
$3=$ Undecided & 9 & 9 \\
$4=$ Agree & 36 & 36 \\
$5=$ Strongly Agree & 44 & 44 \\
\hline Total & 100 & 100 \\
\hline
\end{tabular}

Campaign variables (X3). Variable Promotion consists of four items in the form of statements advertising, promotion, sales, and public relations are used to promote products "KITA" to the community.

Selection of respondents is composed of strongly disagree, disagree, undecided, agree and strongly agree that transformed in the form of a Likert scale of 1 to 5 with the figure 1 shows the perception strongly disagree and 5 indicates strongly agree to statement filed.

The results of descriptive statistics in table shows the majority of respondents gave answers strongly agree by $43(43 \%)$ and agree $34(34 \%)$, undecided $10(10 \%)$, disagree $8(8 \%)$, and strongly disagree $5(5 \%)$.

Table 5. Descriptive Statistics of Promotions

\begin{tabular}{|l|l|l|}
\hline Scale & Frequency & Percentage $\mathbf{( \% )}$ \\
\hline $1=$ Strongly Disagree & 5 & 5 \\
2 = Disagree & 8 & 8 \\
3 = Undecided & 10 & 10 \\
4 = Agree & 34 & 34 \\
$5=$ Strongly Agree & 43 & 43 \\
\hline Total & 100 & 100 \\
\hline
\end{tabular}


Consumer satisfaction variables (Y1). Consumer satisfaction variable views of criteria based on the recommendations of buyers, repeat purchase, and commitment to the buyer. And also consists of four items in the statement of the index measuring consumer satisfaction.

Selection of respondents is composed of strongly disagree, disagree, undecided, agree and strongly agree that transformed in the form of a Likert scale of 1 to 5 with the figure 1 shows the perception strongly disagree and 5 indicates strongly agree on statement filed.

The results in Table 5:10 descriptive statistics show that the majority of respondents strongly agreed with the customer satisfaction on a statement filed as many as 48 answers, or about 48 percent. Agree 42 answers, or about 42 percent, undecided 11 or 11 percent, disagreed 9 or 9 percent, and strongly disagree 6 answers or 6 percent.

Table 6. Descriptive Statistics of consumer satisfaction

\begin{tabular}{|l|l|l|}
\hline Scale & Frequency & Percentage (\%) \\
\hline $1=$ Strongly & 7 & 7 \\
Disagree & & \\
2 = Disagree & 9 & 9 \\
$3=$ Undecided & 11 & 11 \\
$4=$ Agree & 32 & 32 \\
$5=$ Strongly Agree & 41 & 41 \\
\hline Total & 100 & 100 \\
\hline
\end{tabular}

Table 7. Descriptive Statistics of consumer loyalty

\begin{tabular}{|l|l|l|}
\hline Scale & Frequency & Percentage (\%) \\
\hline 1 = Strongly & 6 & 6 \\
Disagree & & 9 \\
$2=$ Disagree & 9 & 11 \\
$3=$ Undecided & 11 & 42 \\
$4=$ Agree & 42 & 48 \\
$5=$ Strongly Agree & 48 & 100 \\
\hline Total & 100 & \\
\hline
\end{tabular}

Consumer loyalty variable (Y2). Variable customer loyalty consists of two dimensions, namely consumer loyalty and post-purchase behavior. With a total of 8 items statement for customer loyalty variable (Y2).

Selection of respondents is composed of strongly disagree, disagree, undecided, agree and strongly agree that transformed in the form of a Likert scale of 1 to 5 with the figure 1 shows the perception strongly disagree and 5 indicates strongly agree on statement filed.

The results of descriptive statistics in Table 5:11 shows the majority of respondents answered strongly agreed with the statement filed with the frequency of 41 answers, or about $41 \%$. While providing answers to agree as much as 32 answers with a percentage of $32 \%$, hesitant answer choices have a frequency of 11 or $11 \%$, followed by the answer which not agree as much as 9 answers or $9 \%$, and the remaining $7 \%$ or 7 answers answered strongly disagree.

Descriptive Statistics Variable Table consumer loyalty.

Validity test. Test validation data in this study carried out by the technical analysis of the items, i.e. by correlating the score of each item questions with a total score for each variable. Correlation technique used in performing the validation test is the Pearson Product Moment. 
Questionnaire research product variable (X1) consists of four items of questions, the results of the correlation calculations to score each of the questions with a total score of each variable can be seen in table as follows:

Table 8. Validity of Test Results Table Variable Products

\begin{tabular}{|l|l|l|l|}
$\begin{array}{l}\text { item } \\
\text { Questions }\end{array}$ & Correlation & $\begin{array}{l}\text { limit } \\
\text { Values }\end{array}$ & Information \\
\hline P1 & 0891 & $0: 30$ & invalid \\
\hline P2 & 0706 & $0: 30$ & invalid \\
\hline P3 & 0407 & $0: 30$ & invalid \\
\hline P4 & 0891 & $0: 30$ & invalid \\
\hline
\end{tabular}

Research questionnaires price variable (X2) consists of four items of questions, the results of the correlation calculations to score each of the questions with a total score of each variable can be seen in the following table:

Table 9. Validity of Test Results Table Variable Price

\begin{tabular}{|l|l|l|l|}
\hline $\begin{array}{l}\text { item } \\
\text { Question }\end{array}$ & Correlation & $\begin{array}{l}\text { limit } \\
\text { Values }\end{array}$ & Information \\
\hline P1 & 0590 & $0: 30$ & invalid \\
\hline P2 & 0615 & $0: 30$ & invalid \\
\hline P3 & 0781 & $0: 30$ & invalid \\
\hline P4 & 0781 & $0: 30$ & invalid \\
\hline
\end{tabular}

Promotion of research questionnaire variables (X3) on 4 items of questions, the results of the correlation calculations to score each of the questions with a total score of each variable can be seen in the following table:

Table 10. Validity of Test Results Table Variable Promotion

\begin{tabular}{|c|c|c|c|}
\hline $\begin{array}{l}\text { item } \\
\text { Questions }\end{array}$ & Correlation & $\begin{array}{l}\text { limit } \\
\text { Values }\end{array}$ & Information \\
\hline$\overline{\mathrm{P} 1}$ & 0697 & $0: 30$ & invalid \\
\hline P2 & 0611 & $0: 30$ & invalid \\
\hline P3 & 0781 & $0: 30$ & invalid \\
\hline P4 & 0647 & $0: 30$ & invalid \\
\hline
\end{tabular}

Consumer satisfaction research questionnaire variables (Y1) consists of four items of questions, the results of the correlation calculations to score each of the questions with a total score of each variable can be seen in the table as follows:

Table 11. Validity of Test Results Table Variable Consumer satisfaction

\begin{tabular}{|c|c|c|c|}
\hline item & \multicolumn{2}{|c|}{ Correlationlimit } & Information \\
\hline Question & & Values & \\
\hline P1 & 0939 & $0: 30$ & invalid \\
\hline P2 & 0377 & $0: 30$ & invalid \\
\hline P3 & 0919 & $0: 30$ & invalid \\
\hline P4 & 0939 & $0: 30$ & invalid \\
\hline
\end{tabular}


Table 12. Correlation values of customer loyalty

\begin{tabular}{|c|c|c|c|}
\hline $\begin{array}{l}\text { item } \\
\text { Questions }\end{array}$ & Correlation & $\begin{array}{l}\text { limit } \\
\text { Values }\end{array}$ & $\begin{array}{l}\text { Informatio } \\
n\end{array}$ \\
\hline P1 & 0891 & $0: 30$ & invalid \\
\hline $\mathrm{P} 2$ & 0704 & $0: 30$ & invalid \\
\hline P3 & 0409 & $0: 30$ & invalid \\
\hline P4 & 0891 & $0: 30$ & invalid \\
\hline P5 & 0891 & $0: 30$ & invalid \\
\hline P6 & 0704 & $0: 30$ & invalid \\
\hline P7 & 0392 & $0: 30$ & invalid \\
\hline P8 & 0891 & $0: 30$ & invalid \\
\hline
\end{tabular}

Customer loyalty research questionnaire variable (Y2) consists of eight items of questions, the results of the correlation calculations to score each of the questions with a total score of each variable can be seen in the following table:

Validity of Test Results Table Variable Consumer Loyalty. Results of testing the validity of item questionnaire showed that all items of questions in a variable product, price, promotion, customer satisfaction, and customer loyalty, has a correlation value above 0.3 as the limit value of an item that said the research questionnaire can be used (acceptable) based on criteria expressed by sugioyono (2016) so that it can be said that the instrument has good construction validity.

Data Reliability Test. According Priyatno (2010: 97) "reliability testing is used to determine the consistency of the measuring instrument, whether the measuring instrument used is reliable and remains consistent if the measurement is repeated". Reliability testing is only done for valid statement items. A measuring device is said to be reliable if the instrument in measuring a symptom at different times always shows the same results.

Reliability testing in this study was carried out using the Alpha method.

Table 13. Reliability Test Results

\begin{tabular}{|l|l|r|l|}
\hline Variable & $\begin{array}{l}\text { Coefficient } \\
\text { Reliabilities }\end{array}$ & Alpha $(\alpha)$ & Summary \\
\hline Product & 0.707 & 0.60 & Reliable \\
\hline Price & 0.633 & 0.60 & Reliable \\
\hline Promotion & 0.622 & 0.60 & Reliable \\
\hline $\begin{array}{l}\text { Consumer } \\
\text { satisfaction }\end{array}$ & 0.793 & 0.60 & Reliable \\
$\begin{array}{l}\text { Consumer } \\
\text { liability }\end{array}$ & 0.871 & 0.60 & Reliable \\
\hline
\end{tabular}

Based on data in table, shows that the numbers of Cronbach's alpha values on all variables in this study, all imply the amount above the value of 0.60 . This means that the whole question of independent and dependent variables is reliable, and it can be concluded that the instrument questionnaire showed reliability in measuring the variables in the research model.

Testing Analysis Model Path (Path Analysis). Path analysis (path analysis) is used to find an explanation for the patterns of relationships between the variables studied based on theoretical considerations and empirical studies that have been done before, and then displayed in the form of an image (path diagram) as a tool to help conceptualization of complex issues.

Step-by-step path analysis modeling (Ridwan and Engkos, 2007) are as follows: 
Designing a path analysis model based on the concept and previous research, it developed a theoretical model that is:

1. Variable marketing strategy, which consists of a Product (X1), Price (X2), promotion (X3) directly influence customer satisfaction (Y1)

2. Variable marketing strategy, which consists of a Product (X1), Price (X2), promotion (X3) a direct effect on consumer loyalty (Y2)

3. Consumer satisfaction variables (Y1) directly influence consumer loyalty (Y2)

4. Variable marketing strategy, which consists of a Product (X1), Price (X2), promotion (X3) indirect effect on consumer loyalty (Y2) through consumer satisfaction (Y1)

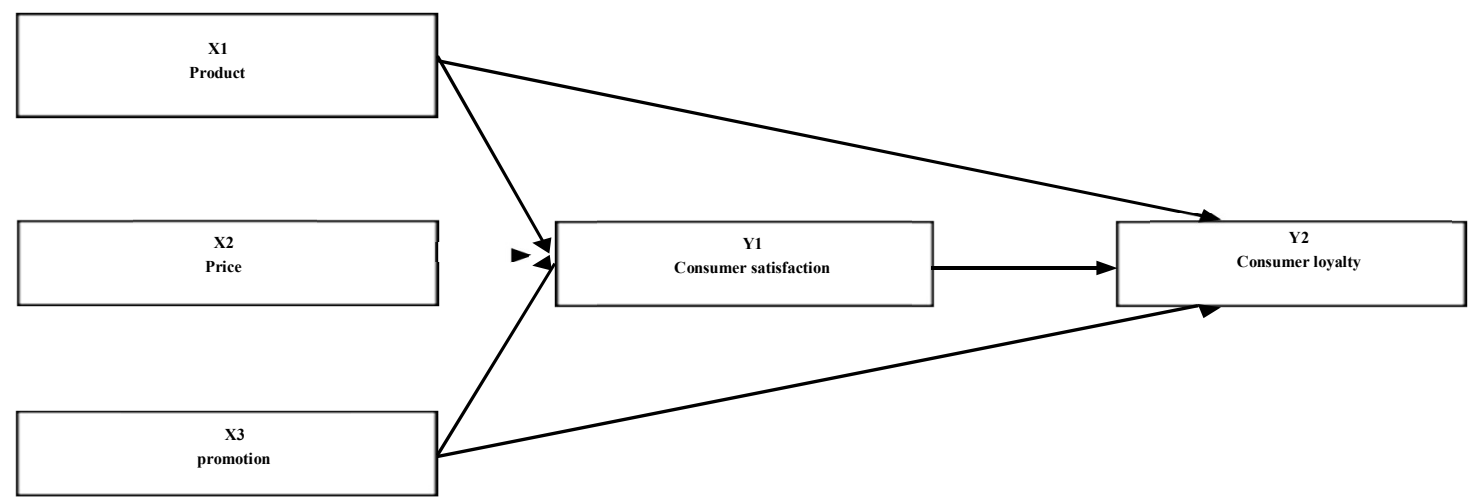

Figure 1. Path Analysis Model

The calculation of the path coefficients using software Statistical Product and Service Solutions (SPSS) version 22 through the analysis of partial regression where the coefficients track the regression coefficients standardized (standardized coefficients beta) for its direct impact, while the indirect effect is obtained by multiplying the path coefficient of the path traversed each equation and the total effect is the sum of the direct influence of the entire indirect influence. Here are the results of the analysis of the substructure of the calculation in the appendix.

$\mathrm{Y} 1=\rho \mathrm{Y} 1 \mathrm{X} 1+\rho \mathrm{Y} 1 \mathrm{X} 2+\rho \mathrm{Y} 1 \mathrm{X} 3+\mathrm{C} 1 \quad$ Substructure 1

$\mathrm{Y} 2=\rho \mathrm{Y} 2 \mathrm{X} 1+\rho \mathrm{Y} 2 \mathrm{X} 2+\rho \mathrm{Y} 2 \mathrm{X} 3+\rho \mathrm{Y} 2 \mathrm{Y} 1+\epsilon 2 \quad$ Substructure 2

INFLUENCE DIRECTLY VARIABLE PRODUCTS, PRICES, AND PROMOTION ON CUSTOMER SATISFACTION

In phase 1 is a structural equation

$\mathrm{Y} 1=\rho \mathrm{Y} 1 \mathrm{X} 1+\rho \mathrm{Y} 1 \mathrm{X} 2+\rho \mathrm{Y} 1 \mathrm{X} 3+\mathrm{E} 1$

Where:

$\mathrm{X} 1=$ Product

$\mathrm{X} 2=$ Price 
Table 14. Calculation results

\begin{tabular}{|c|c|c|c|c|c|}
\hline \multirow[t]{2}{*}{ Model } & \multicolumn{2}{|c|}{$\begin{array}{l}\text { Coefficients } \\
\text { unstandardized }\end{array}$} & \multirow{2}{*}{\begin{tabular}{|l}
$\begin{array}{l}\text { standardized } \\
\text { Coefficients }\end{array}$ \\
beta
\end{tabular}} & \multirow[t]{2}{*}{ l } & \multirow[t]{2}{*}{ Sig. } \\
\hline & B & Std. Error & & & \\
\hline $\begin{array}{l}\text { (Constan } \\
\text { t) } \\
\text { PRODU } \\
\text { CT } \\
\text { PRICE } \\
\text { PROMO } \\
\text { TION }\end{array}$ & $\begin{array}{|rr|} & -.884 \\
& \\
-.628 & \\
1,621 & \\
& .058 \\
\end{array}$ & $\begin{array}{l}.053 \\
.061 \\
\end{array}$ & $\begin{array}{l}-.583 \\
1,394 \\
.058\end{array}$ & $\begin{array}{r}-1743 \\
-11819 \\
26676 \\
2,053\end{array}$ & $\begin{array}{l}.083 \\
000 \\
.000 \\
042\end{array}$ \\
\hline
\end{tabular}

$\mathrm{X} 2=$ promotion

$\mathrm{Y} 1=$ consumer satisfaction

To calculate the regression equation:

Table 15. Model Summary

\begin{tabular}{|c|c|c|c|c|}
\hline Model & $\mathrm{R}$ & R Square & $\begin{array}{l}\text { adjusted R } \\
\text { Square }\end{array}$ & $\begin{array}{l}\text { Std. Error of } \\
\text { the } \\
\text { estimate }\end{array}$ \\
\hline 1 & $.957 \mathrm{a}$ & .916 & .914 & .709 \\
\hline
\end{tabular}

Predictors: (Constant), PROMOTION, PRICE, PRODUCT

Table 16. ANOVAa

\begin{tabular}{|l|r|r|l|l|l|}
\hline Model & $\begin{array}{l}\text { Sum of } \\
\text { Squares }\end{array}$ & df & $\begin{array}{l}\text { mean } \\
\text { Square }\end{array}$ & F & Sig. \\
\hline Regression & 831722 & 3 & 277241 & 551 & .000 \\
211 & $\mathrm{~b}$ \\
$1 \begin{aligned} \text { residual } \\
\text { Total }\end{aligned}$ & 90817431 & 152 & .503 & & \\
\hline
\end{tabular}

Predictors: (Constant), PROMOTION, PRICE, PRODUCT

\section{Coefficientsa}

Dependent Variable: Customer Satisfaction. Based on the analysis using SPSS, above it can be concluded that the variable product, price, and promotion of consumer satisfaction is able to explain the variable that is equal to $91.6 \%$ while the rest influenced by other factors in addition to the three factors proficiency level. The partial effect of each variable is:
a.
Influence
directly
variable
product
to variable
consumer

satisfaction can be seen from the standardized coefficient is X1 $->\mathrm{Y} 1=\rho 1=-0583$ 
Table 17. Calculation results of a direct influence between product and consumer satisfaction

\begin{tabular}{|l|r|r|r|l|l|}
\hline Model & $\begin{array}{l}\text { Sum of } \\
\text { Squares }\end{array}$ & df & $\begin{array}{r}\text { mean } \\
\text { Square }\end{array}$ & Sig. \\
\hline Regressio & 3103.931 & 4 & 775983 & 16591.446 & $.000 \mathrm{~b}$ \\
$\mathrm{n}$ & 7,062 & 151 & .047 & & \\
lresidual & 3110.994 & 155 & & & \\
Total & & & \\
\hline
\end{tabular}

b. The direct effect of price variables to variable customer satisfaction can be seen from the standardized coefficient is $\mathrm{X} 2->\mathrm{Y} 1=\rho 2=1,394$

c. The direct effect of promotion variable to variable customer satisfaction can be seen from the standardized coefficient is $\mathrm{X} 3->\mathrm{Y} 1=\rho 3=0.058$

Table 18. Overall calculation results of independent variables influence on consumer satisfaction

\begin{tabular}{|c|c|c|c|c|c|}
\hline \multirow[t]{2}{*}{ Model } & \multicolumn{2}{|c|}{$\begin{array}{c}\text { Coefficients } \\
\text { unstandardized }\end{array}$} & $\begin{array}{c}\text { Standardized } \\
\text { coefficients }\end{array}$ & \multirow[t]{2}{*}{$\mathrm{t}$} & \multirow[t]{2}{*}{ Sig. } \\
\hline & B & Std. Error & beta & & \\
\hline \multirow{5}{*}{$\begin{array}{r}\text { (Constant) } \\
\text { PRODUCT } \\
\text { PRICE } \\
\text { PROMOTION } \\
\text { CUSTOMER SATISFACTION }\end{array}$} & .071 & .156 & & .452 & .652 \\
\hline & 2075 & .022 & 1,040 & 92372 & .000 \\
\hline & -.217 & .044 & -.101 & -4912 & .000 \\
\hline & .029 & .009 & .016 & 3,288 & .001 \\
\hline & .109 & .025 & .059 & 4,409 & .000 \\
\hline
\end{tabular}

Based on the test results of structural equation 1, the third free variable (product, price and simultaneous promotion in the amount of $91.6 \%$ were able to explain the level of customer satisfaction. Variable products negative effect and significant at the $1 \%$ level, while for variable pricing and promotion have a positive relationship with the level of significance of $1 \%$ for variable influence the price and for the variable of promotion is significant at the $5 \%$ level. Furthermore, the influence of causal empirical between product variables (X1), a price variable (X2) and variable promotion $(\mathrm{X} 3)$ can be described by an equation sub-structural 1 (one).

$$
\mathrm{Y} 1=\rho \mathrm{Y} 1 \mathrm{X} 1+\rho \mathrm{Y} 1 \mathrm{X} 2+\rho \mathrm{Y} 1 \mathrm{X} 3+\mathrm{C} 1 \text { or } \mathrm{Y} 1=-.583 \mathrm{X} 1+1.394 \mathrm{X} 2+0.058 \mathrm{X} 3+\mathrm{C} 1
$$

Variable Direct Effect of Product, Price, Promotion, And Customer Satisfaction on Customer Loyalty.

Table 19. Model Summary of model

\begin{tabular}{|l|l|l|l|l|}
\hline Model & $\mathrm{R}$ & R Square & $\begin{array}{l}\text { adjusted R } \\
\text { Square }\end{array}$ & $\begin{array}{l}\text { Std. error } \\
\text { of } \\
\text { the } \\
\text { Estimate }\end{array}$ \\
\hline 1 & $.999 \mathrm{a}$ & .998 & .998 & .216 \\
\hline
\end{tabular}

Predictors: (Constant), CUSTOMER SATISFACTION, PROMOTION, PRICE, PRODUCT

Based on the analysis using SPSS, above it can be concluded that the variable product, price, promotion, and consumer satisfaction Consumer loyalty is able to explain variable that is equal to $99.8 \%$ while the rest influenced by other factors in addition to the three factors proficiency level. The partial effect of each of these variables are: 
1. The direct effect of product variables to variable customer loyalty can be seen from the standardized coefficient is $\mathrm{X} 1->\mathrm{Y} 2=\rho 4=1.040$

2. The direct effect of price variables to variable customer loyalty can be seen from the standardized coefficient is $\mathrm{X} 2->\mathrm{Y} 2=\rho 5=-0101$

3. The direct effect of promotion variable to variable customer loyalty can be seen from the standardized coefficient is $\mathrm{X} 3->\mathrm{Y} 2=\rho 6=0.016$

4. The direct effect of consumer satisfaction variable to variable customer loyalty can be seen from the standardized coefficient is $\mathrm{Y} 1>\mathrm{Y} 2=\rho 7=0.059$

Simultaneously, the influence of X1, X2, X3, and Y1 to Y2 is equal to 0998 (99.8\%), remaining $0.2 \%$ influence of other factors outside the model. Simultaneous Model has been significant. With regard to the probability of $\mathrm{F}$ amounted 16591.446 significance of 0.000 (level 1\%). Once the model has proved significant simultaneous, then do a search path partial effect. Of the four variables are placed as a predictor, a variable product, price, promotion, and consumer satisfaction have significant value for the level $1 \%$ so it can be said that the entire predictor partially influence on consumer loyalty (Y2). Directly variable products, variable price promotion variables and variable customer satisfaction significant positive effect on customer loyalty. The magnitude of the direct influence on consumer loyalty product variable is equal to 0,$000 ; 0.000 ; 0,001 ; 0,000$. That is, the level of consumer loyalty towards Pajero car is affected by the variable products, pricing and promotions, customer satisfaction is almost perfect, namely $99.9 \%$ identified as.

The strongest variables that influence loyalty. The remaining $0.1 \%$ influenced by other factors outside the model.

Based on the test results of structural equation 2, the four independent variables (product, price, promotion, and customer satisfaction) simultaneously able to explain the customer loyalty that is equal to $99.8 \%$. products, promotions, and customer satisfaction is a positive and significant effect on the level of $1 \%$, while for variable price has a negative effect with a significance level of $1 \%$. Furthermore, empirical causal effect between product variables (X1), a price variable (X2) and promotional variable (X3) and customer satisfaction (Y1) can be described by an equation of structural sub 2 (two).

$$
\begin{aligned}
& \mathrm{Y} 2=\rho \mathrm{Y} 2 \mathrm{X} 1+\rho \mathrm{Y} 2 \mathrm{X} 2+\rho \mathrm{Y} 2 \mathrm{X} 3+\rho \mathrm{Y} 2 \mathrm{Y} 1+\epsilon 2 \text { or } \\
& \mathrm{Y} 2=1.040 \mathrm{X} 1-0.101 \mathrm{X} 2+0.016 \mathrm{X} 3+0.059 \mathrm{Y} 1+\epsilon 2
\end{aligned}
$$

Based on the test results in the equation phase 1 and phase 2 is obtained empirical path diagram for the model image Y2 as described below:

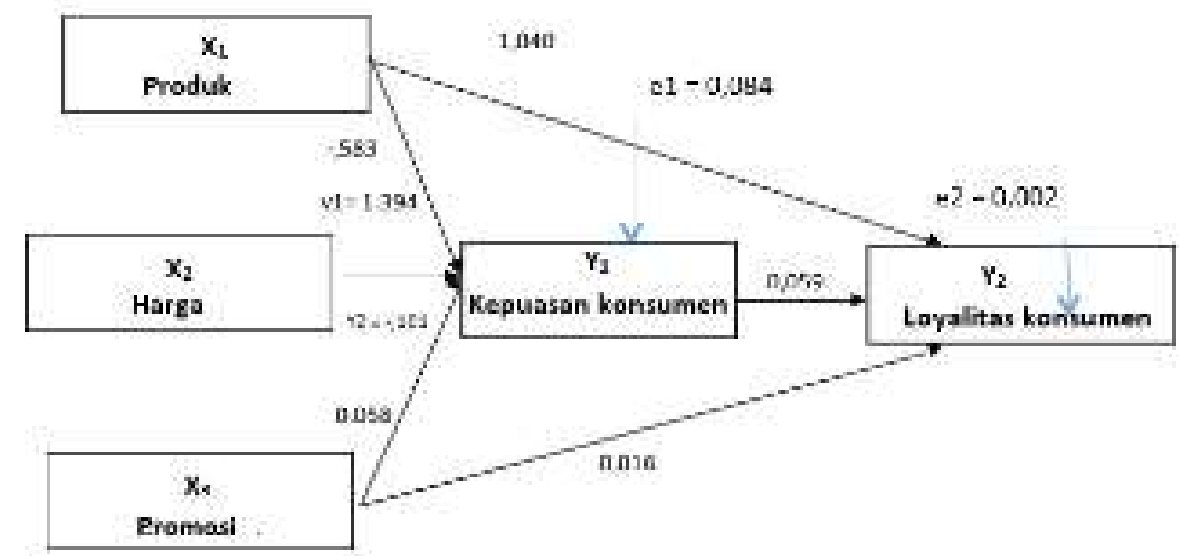

Figure 2. Model Result Analysis Path 
Table 20. Lines 1 and 2

\begin{tabular}{|c|c|c|c|c|}
\hline Model & coefficient Line & & p & $R^{2}$ \\
\hline \multicolumn{5}{|c|}{ Sub Structural 1 (X1, X2, X3 to Y1) } \\
\hline $\mathrm{X} 1(\rho \mathrm{Y} 1 \mathrm{X} 1)$ & 0583 & 11819 & 0000 & \multirow{3}{*}{0.916} \\
\hline $\mathrm{X} 2(\rho$ Y1X2) & 1,394 & 26676 & 0000 & \\
\hline $\mathrm{X} 3(\rho \mathrm{Y} 1 \mathrm{X} 3)$ & 0058 & 2,053 & $\overline{0042}$ & \\
\hline \multicolumn{5}{|c|}{ Sub Structural 2 (X1, X2, Y1 to Y2) } \\
\hline $\mathrm{X} 1(\rho \mathrm{yX} 1)$ & 1,040 & 92372 & 0000 & \multirow{4}{*}{0,998} \\
\hline $\mathrm{X} 2(\rho \mathrm{yX} 2)$ & .101 & 4912 & 0000 & \\
\hline X3 ( $\rho$ yX3) & 0,016 & 3,288 & 0001 & \\
\hline Y1 ( $\rho$ yY2) & 0.059 & 4,409 & 0000 & \\
\hline
\end{tabular}

Summary and coefficient based on lines 1 and 2 it can be seen the influence of direct, indirect effect and the total effect between variables.

Product variables influence to variable customer loyalty through customer satisfaction variables were obtained by using the formula:

$$
\begin{aligned}
& \mathrm{X} 1->\mathrm{Y} 1->\mathrm{Y} 2 \quad=(\mathrm{P} 1 \times \rho 7) \\
& =(0.583 \times 0.059) \\
& =0.0343947 \\
& =0,034
\end{aligned}
$$

A value of 0.034 means that the indirect effect of the decision-making variable products through consumer satisfaction variable is equal to 0,034 or 3.4 percent.

The influence of the price variable to variable customer loyalty through customer satisfaction variables were obtained by using the formula:

$$
\begin{aligned}
\mathrm{X} 2->\mathrm{Y} 1->\mathrm{Y} 2 & =(\rho 2 \times \rho 7) \\
= & (0.0591,394 . \mathrm{x}) \\
& =0.082246 \\
& =0.082
\end{aligned}
$$

A value of 0.082 means that the indirect influence of variables prices on consumer loyalty through customer satisfaction variable is equal to 00.082 , or 8.2 percent.

Effect of promotion variable to variable customer loyalty through customer satisfaction variables were obtained by using the formula:

$$
\begin{aligned}
\mathrm{X} 3->\mathrm{Y} 1->\mathrm{Y} 2 & =(\mathrm{x} \rho 3 \rho 7) \\
= & (0.0590,058 . \mathrm{x}) \\
& =0.003422 \\
& =0.0034
\end{aligned}
$$

A value of 0.0034 means that the indirect influence promotion variable to variable customer loyalty through customer satisfaction variable is equal to 0.0034 or 0.34 percent.

Effect of Total. The net effect is obtained from the calculation using the formula:

Total Effect $=$ direct effects + indirect effect

$$
=\mathrm{P} 4+(\rho 1 \times \rho 7)
$$




$$
\begin{aligned}
& =1.040+(0.583 \times 0.059) \\
& =1.074397 \\
& =1,074
\end{aligned}
$$

The net effect of products on consumer loyalty through customer satisfaction amounted to 1,074 , or 107.6 percent.

The net effect is obtained from the calculation using the formula:

Total Effect $=$ direct effects + indirect effect

$$
\begin{aligned}
& =\mathrm{P} 5+(\rho 2 \times \rho 7) \\
& =0,101+(1.394 \times 0.059) \\
& =0.183246 \\
& =0183
\end{aligned}
$$

The influence of the total price of consumer loyalty through customer satisfaction is at 0183 , or 18.3 percent.

The net effect is obtained from the calculation using the formula:

Total Effect $=$ direct effects + indirect effect

$=\mathrm{P} 6+(\rho 3 \times \rho 7)$

$=0.016+(0.058 \times 0.059)$

$=0.019422$

$=0.0194$

Effect of total promotions on consumer loyalty through customer satisfaction is at 0.0194 , or 1.94 per cent.

Table 21. Effect of Total

\begin{tabular}{|l|r|l|l|}
\hline VARIABLE & $\begin{array}{l}\text { DIRECT } \\
\text { EFFECT } \\
(\mathrm{PL})\end{array}$ & $\begin{array}{l}\text { EFFECT OF } \\
\text { INDIRECT } \\
(\text { PTL })\end{array}$ & $\begin{array}{l}\text { EFFECT OF } \\
\text { TOTAL }\end{array}$ \\
\hline Products $(\mathrm{X} 1)$ & 1,040 & 0,034 & 1,074 \\
\hline Price $(\mathrm{X} 2)$ & .101 & 0.082 & 0183 \\
\hline Promotion $(\mathrm{X} 3)$ & 0,016 & .0034 & 0.0194 \\
\hline \hline TOTAL & 0955 & 0.0514 & 1.2764 \\
\hline
\end{tabular}

The next step is an examination of the validity of the model. There are two indicators to examine the validity of the model is the coefficient of determination total the results can be presented as follows: Results Coefficient total Determinant.

Error Term $(\mathrm{e} 1)=\sqrt{ } 1-\mathrm{R} 2$

$=\sqrt{ } 1-.916=0,290$

$\mathrm{R} 2 \mathrm{~m}=1-(\mathrm{e} 1)$ second $(\mathrm{e} 2) 2$

$\mathrm{R} 2 \mathrm{~m}=1-(0,290) 2(0,045) 2$

$\mathrm{R} 2 \mathrm{~m}=1-(0.0841)(0.002025)$

$\mathrm{R} 2 \mathrm{~m}=1-(0.0001703025)$

$\mathrm{R} 2 \mathrm{~m}=0.9998296975$

Based on the calculation formula coefficient of determination total they obtained that the diversity of the data obtained is explained by the model is 99.98 percent, or in other words, the information contained in the data amounted to 99.98 percent can be explained by the model, while the remaining 0.02 percent is explained by other variables ( not included in the model) and error. 
Hypothesis testing. The following hypothesis test the effect of each variable in the study:

Statistics hypotheses to test significant influence marketing strategy that consists of product, price, and promotion of consumer loyalty are as follows:

H0: There is no significant influence between the variables Marketing Strategies consist of product, price, and promotion of consumer loyalty.

H1: There is a significant influence between the variables Marketing Strategies consist of product, price, and promotion of consumer loyalty.

There is a significant positive effect between Marketing Strategies consist of product, price, and promotion of consumer loyalty.

This result is reinforced by the results of the F test (ANOVA) which states that Fcount (16591.446) is greater than Ftable (2.43), and significant with a probability of $0.000(\mathrm{p}<0.05)$. The magnitude of the influence of marketing strategies on consumer loyalty can be seen in the calculation of the coefficient of determination that is equal to 0.998 or $99.8 \%$. The results of this test explain that there are significant effects of product variables, prices and promotion of consumer loyalty. so H0 is rejected. Thus the hypothesis is accepted.

Hypothesis Statistics to test the significant effect of Marketing Strategy Variables consisting of products, prices, and promotion of consumer loyalty are:

H0: There is no significant effect between the Marketing Strategy variables which consist of products, prices, and promotion of consumer satisfaction. H1 : There is a significant effect between the Marketing Strategy variables which consist of products, prices, and promotion of consumer satisfaction.

There is a significant positive influence between marketing strategies on consumer satisfaction. This result is reinforced by the results of the $\mathrm{F}$ test (ANOVA) which states that Fcount $(551,211)$ is greater than Ftable (2.43), and significant with a probability of $0,000(\mathrm{p}<0,05)$. As for the influence of Marketing Strategy on consumer loyalty can be seen in the calculation of the determination coefficient of 0.916 or $91.6 \%$. The results of this test explain that there are significant influences of product, price, and promotion variables on consumer satisfaction. So that $\mathrm{H} 0$ is rejected. Thus the hypothesis is accepted.

The statistical hypothesis for testing consumer satisfaction has a significant effect on consumer loyalty:

H0: There is no significant effect between the variables of consumer satisfaction on consumer loyalty. H1: There is a significant effect between the variables of consumer satisfaction on consumer loyalty. The results of path analysis show that customer satisfaction has a significant influence on consumer loyalty. The effect of variable consumer satisfaction on purchasing decisions is indicated by the path coefficient value $(\square)$ of 0.059 with a probability of $0.000(\mathrm{p}>0.05)$. The results of this test explain that there is a significant effect of the variable customer satisfaction on the variable customer loyalty with a direct influence of 0.059 . So the hypothesis $\mathrm{H} 0$ is rejected. therefore. Thus the hypothesis is accepted.

Statistical hypothesis test there are significant variables Marketing Strategies consist of product, price, and promotion of customer loyalty with customer satisfaction as an intervening variable is:

H0: There are currently no influence between variable product, price, and promotion of customer loyalty with customer satisfaction as an intervening variable

H1: There is influence between the variables of product, pricing, and promotion of customer loyalty with customer satisfaction as an intervening variable

In the analysis results are not immediately visible effect of the product on consumer loyalty through customer satisfaction as an intervening variable, in this case the indirect effect is 0.0514 . But the intervening coefficient value of 0.0514 is smaller than the value of the direct influence of 0955 . so that the intervening variable is not proven. So H0 is accepted. Thus the hypothesis is rejected. 


\section{Conclusion}

Based on the results of research and discussion, then a number of conclusions as follows:

1. Variable marketing strategy consists of product, price, and promotion of significant effect on customer loyalty (Y2). This means that if the enhanced marketing strategy will have an impact on the increase in the purchase of products "KITA".

2. Variable marketing strategy consists of product, price, promotion and significant effect on customer satisfaction. This means that if the enhanced marketing strategy will have an impact on the increase in customer satisfaction in the purchase of products "KITA"

3. Variable customer satisfaction (Y1) have a significant effect on consumer loyalty (Y2) means that if the customer satisfaction improved then it will have an impact on improving decision-making in the purchase of products "KITA".

4. Variable marketing strategy consisting of the product (X1), price (X2) and promotion (X3) on consumer loyalty there is no influence on customer satisfaction as an intervening variable in Bulog Subdivre.

\section{References}

Ali,Hasan. 2008. Marketing. Media Utama, Yogyakarta.

Arikunto, Suharsimi. 2002. Metodologi Penelitian. Penerbit PT. Rineka Cipta. Jakarta.

Arif SA, Zulkarnain I. 2008. Dasar-Dasar Manjemen Dalam Teknologi Informasi.Jurnal Saintikom Vol. 5 No. 2

Augusty, F. 2005. Structural Equation Model dalam Penelitian Manajemen, Aplikasi Model-Model Rumit Dalam Penelitian Untuk Tesis Magister Dan Disertasi Doktor Badan Penerbit Universitas Diponegoro, Semarang.

Azwar, Saefuddin. 1997. Reliabilitas dan Validitas. Edisi Ketiga. Pustaka Pekerja, Yogyakarta

Bambang Sarjono. 2011. Studi Tentang Penerapan Strategi Pemasaran Dalam Penjualan Produk White Board Doble Sid. Jurnal ORBITH Vol. 7 No. 3 November 2011: 429-436

Bastian AD. 2014. Analisi Pengaruh Citra Merek (Brand Image) dan Ke- percayaan Merek (Brand Trust) terhadap Kepuasan konsumen (Brand Loyal- ity) ADES PT. Ades Alfindo Putra Setia.Jurnal Manajemen Pemasaran Petra Vol.2 No.1

Griffin, Jill. 2002. Customer Loyalty How to Earn It, How to Keep It.

Iskandar K. dan Andriyani W. 2014. Pengaruh Strategi Pemasaran Terhadap Penjualan Batubara Pada PT. Cahaya Mantingan Nusantara Jakarta. jurnal ekonomi kuantitatif terapan. Vol. 7 No. 1 Februari 2014.

Jonathan Sarwono. 2007. Analisis Jalur Untuk Riset Bisnis dengan SPSS. Yogyakarta : Penerbit Andi Kotler dan Keller, 2007. Manajemen Pemasaran, Edisi 12, Jilid 1, PT.Indeks, Jakarta.

Kotler, Philip dan Gary Armstrong, 2001, Prinsip-prinsip Pemasaran, Jilid 1, Edisi Kedelapan, Jakarta, Erlangga.

Kotler, Philip dan Kevin Lane Keller, 2008. Manajemen Pemasaran, Jilid 1, Penerbit Erlangga. Jakarta.

Kotler, Philip. 2001. Manajemen Pemasaran : Analisis, Perencanaan, Implementasi, dan Kontrol. Jakarta : PT. Prehallindo

Kotler, Philip dan Keller, K.L., 2009. Manajemen Pemasaran, Edisi ke 13, Jilid 1, Erlangga, Jakarta Mangilep, M. A. A. (2015). Socioeconomic Problems on Adoption of New Technologies for Production of Paddy Rice by Farmers in Upland Areas of South Sulawesi. 千葉大学人文社会 科学研究, 千葉大学人文社会科学研究 (30), 150-157, 2015-03, 千葉大学大学院人文社会 科学研究科. Retrieved from https://ci.nii.ac.jp/naid/120005940591/ 